\title{
Salinity tolerance of macroalgae Gracilaria birdiae
}

\author{
Joseanna de Paiva Alves ${ }^{*}$ (D) Ambrosio Paula Bessa Junior ${ }^{2}$ (D) Gustavo Gonzaga Henry-Silva ${ }^{3}$ \\ ${ }^{1}$ Programa de Pós-graduação em Ciência Animal, Universidade Federal Rural do Semi-Árido (UFERSA), 59625-900, Mossoró, RN, Brasil. \\ E-mail: joseannapaiva@hotmail.com. "Corresponding author. \\ ${ }^{2}$ Centro de Ciências Agrárias, Universidade Federal Rural do Semi-Árido (UFERSA), Mossoró, RN, Brasil. \\ ${ }^{3}$ Centro de Ciências Biológicas e da Saúde, Universidade Federal Rural do Semi-Árido (UFERSA), Mossoró, RN, Brasil.
}

ABSTRACT: This study aimed to determining the manner in which salinity influenced the growth of the macroalgae Gracilaria birdiae, with the objective of identifying its tolerance limits to this abiotic variable. The specimens were submitted to nutrient-enriched water of varying salinities (0, 10, 20, 30, 40, 50, and 60 ppt) for a 30-day period. Initially, under extreme salinity conditions (0 and 60 ppt) the growth of the $G$. birdiae suffered a negative impact. The macroalgae biomass exposed to 0 and 10 ppt salinities showed a reduction from day six until the experiment was completed. The macroalgae biomass exposed to salinities 20, 30, 40, and 50 ppt showed an increase, with no significant differences between the four treatments. This suggested that this salinity range was comfortable for this species to develop. We concluded that salinity is a crucial parameter which controls the growth of the G. birdiae. This seaweed was negatively influenced when exposed to values equal to or below 10 ppt and equal to 60 ppt, demonstrating good tolerance to salinities of 20, 30, 40 and 50 ppt.

Key words: growth, saline stress, limiting factor.

Tolerância à salinidade da macroalga Gracilaria birdiae

RESUMO: Objetivamos com o presente trabalho avaliar os efeitos da salinidade sobre o crescimento da macroalga Gracilaria birdiae, visando identificar os seus limites de tolerância a esta variável abiótica. Os exemplares foram submetidos a água com salinidades 0 , 10 , 20, 30, 40, 50 e 60 ppt enriquecida com nutrientes por um periodo de 30 dias. Inicialmente a G. birdiae foi negativamente afetada em condições de salinidades extremas (0 e 60 ppt). A biomassa das macroalgas expostas a salinidade 0 e 10 ppt declinou a partir do $6^{\circ}$ dia até o final do experimento. Houve aumento na biomassa das macroalgas expostas as salinidades 20, 30, 40 e 50 ppt, não apresentando diferenças significativas entre estes quatro tratamentos, sugerindo este intervalo de salinidade como sendo ótimo para o desenvolvimento desta espécie. Concluímos que a salinidade é um parâmetro importante para controlar o crescimento da G. birdiae, sendo afetada negativamente quando exposta a valores igual ou menor que 10 ppt e igual a 60 ppt, possuindo tolerância às salinidades de 20, 30, 40 e 50 ppt.

Palavras-chave: crescimento, estresse salino, fator limitante.

\section{INTRODUCTION}

In general, macroalgae cultivation shows high productivity, with genus Gracilaria (red algae) ranking among the most cultivated of the marine vegetables. In fact, the compounds and extracts find use in several economic applications (STENGEL et al., 2015; FAO, 2018; TORRES et al., 2019). The macroalgal biomass is used in phycolloid industries as a potential agar source, while its processed extracts have rheological or bioactive characteristics which are beneficial as dietary supplements, in cosmetics and for animal feed (PEREIRA \& YARISH, 2008; LERAT et al., 2018). Macroalgae are also extensively employed in agriculture, enhancing the productivity of the crop and raising their tolerance levels to overcome biotic and abiotic stresses (BATTACHARYYA, 2015). They are also used in aquaculture, as they have bioremediation efficiency, particularly in terms of nutrient removal from water (MARINHO -SORIANO, 2008).

Living beings exhibit a variety of tolerance limits to the different abiotic variables that they are exposed to in order to survive, grow and reproduce. Salinity ranks high among these variables and is considered one of the most significant, which can influence the metabolism and reproductive capacity of aquatic organisms (WHARTON, 2002; PEREIRA et al., 2017; FATH, 2018). Salinity can also control 
several ecological and biological aspects of the benthic marine algae, such as a species of red algae, Gracilaria birdiae, which flourishes along coastal regions, where the salinity values reveal a high variation range due to the wind, precipitation and tide actions (SCHMIDT et al., 2015; PEREIRA et al., 2017).

A good understanding of the tolerance limits of the abiotic variables, including salinity, is of practical importance to feasibly cultivate many macroalgae species (KALIAPERUMAL et al., 2001; KALIAPERUMAL et al., 1993). In fact, CHOI et al., (2010), in their evaluation of the ways in which the salinity affects the growth, photosynthetic activity and the internal nutrient composition of Ulva pertusa, reported salinity to exert greater influence, more than the other environmental factors, like light and temperature. In their evaluation, PEREIRA et al., (2017) studied the effects of salinity on the physiology of the macroalgae Acanthophora spicifera, and reported that extreme salinities lowered the growth rate in this species. From the data given above, our goal in this study was to estimate how salinity affected the $G$. birdiae macroalgal growth. As this alga is widely distributed along the coastal regions of northeastern Brazil, this study was done to determine its tolerance limits in order to provide information that can facilitate its cultivation because there is a limited number of studies on the effect of salinity on its growth.

\section{MATERIALS AND METHODS}

Individual samples were drawn from the macroalgae Gracilaria birdiae along the coastal region of the state of Ceará - Brazil (3 13'06.1' S and 39
15 ',51.4" W). The manual collection was done during the low tide, and only those individuals showing good physiological condition, with no signs of depigmentation were selected. The plant material was then packed in isothermal boxes with water drawn from the habitat itself and transported to the Aquaculture Sector of the Federal Rural University of the Semi-Arid Region, where this experiment was performed.

A completely randomized experimental design was adopted. The treatments included several salinities $(0,10,20,30,40,50$ and $60 \mathrm{ppt})$ with three replicates each, to account for a total of 21 experimental units, each with 40 liters, using the reference value (control) of $30 \mathrm{ppt}$ (meaning, the identical salinity of the seawater from where the macroalgae were collected). Salinities of 10 and 20 ppt were achieved by adding fresh water to the seawater, while salinities above 30 (40, 50 and $60 \mathrm{ppt}$ ) were obtained by adding hypersaline water from saline. Freshwater was used to achieve zero ppm salinity. All the experimental units were enriched by the addition of von Stosch (VS) solution (Table 1), prepared according to EDWARDS (1970), including the modifications, according to YOKOYA (1996). Constant aeration was provided throughout the 30-day experiment.

In each experimental unit, the macroalgae had initial fresh biomass of $40 \mathrm{~g}$, which corresponded to $6.5 \mathrm{~g}$ of dry mass. In this experiment, the dry mass of the macroalgae used was estimated from the linear regression equation between the fresh mass (MF) and dry mass (MS) of the macroalgae collected from the same place as the individuals used in the experiment $\left(\mathrm{MS}=0.0018+0,1644^{*} \mathrm{MF}(\mathrm{r} 2=0.9819 ; \mathrm{n}=28)\right)$.

The macroalgae were weighed (fresh mass) once in every three days and then replaced

Table 1 - Chemical composition of von Stosch's nutrient solution prepared according to EDWARDS (1970), with modifications according to YOKOYA (1996).

\begin{tabular}{lc}
\hline Components & Concentration per liter \\
\hline $\mathrm{NaNO} 3$ & $0.50 \mathrm{mM}$ \\
$\mathrm{Na} 2 \mathrm{HPO} 4.12 \mathrm{H} 2 \mathrm{O}$ & $30 \mu \mathrm{M}$ \\
$\mathrm{FeSO} 4.7 \mathrm{H} 2 \mathrm{O}$ & $1 \mu \mathrm{M}$ \\
$\mathrm{MnCl} 2.4 \mathrm{H} 2 \mathrm{O}$ & $0.1 \mu \mathrm{M}$ \\
$\mathrm{Na} 2 \mathrm{EDTA} .2 \mathrm{H} 2 \mathrm{O}$ & $10 \mu \mathrm{M}$ \\
Tiamina.HCl & $0.59 \mu \mathrm{M}^{*}$ \\
Biotina & $4.10 \mathrm{nM}^{*}$ \\
Cianocobalamina & $1.0 \mathrm{nM}^{*}$ \\
\hline
\end{tabular}

* Concentration equivalent to $50 \%$ in relation to the original composition proposed by Edwards (1970). 
Table 2 - Average values and standard deviations of the physical and chemical variables of the water, where the $G$. birdiae individuals were grown.

\begin{tabular}{lcc}
\hline Environmental parameters & Average & Standard deviation \\
\hline Temperature $\left({ }^{\circ} \mathrm{C}\right)$ & 28.1 & 0.16 \\
$\mathrm{pH}$ & 9.5 & 0.27 \\
Dissolved oxygen $\left(\mathrm{mg} \mathrm{L}^{-1}\right)$ & 5.0 & 0.73 \\
Total dissolved solids $\left(\mathrm{g} \mathrm{L}^{-1}\right)$ & 24.8 & 14.96 \\
\hline
\end{tabular}

in their respective experimental units. For the characterization of the cultivation environment, the values of temperature, dissolved oxygen, $\mathrm{pH}$, salinity, and total dissolved solids were measured parallel to the biomass determination of macroalgae utilizing the Horiba U50 brand multi-sensor and a portable refractometer (Table 2). The data referring to the dry biomass were analyzed employing the ShapiroWilk and Bartlett tests to determine the normality and homoscedasticity, respectively. For variables showing normal distribution and homogeneous variance, the analysis of variance (one-way ANOVA) was applied and a posteriori the Tukey test, to identify the significant differences $(\mathrm{P}<0.05)$ between the treatments.

\section{RESULTS AND DISCUSSION}

The G. birdiae had initial average biomass of $34.3 \mathrm{gMS} . \mathrm{m}^{-2}$, which showed no significant difference between treatments $(\mathrm{P}=0.8437)$ (Figure 1). On day three of the cultivation, the biomass significantly reduced at the extreme salinity conditions, that is, at 0 and 60 ppt. However, under the conditions of salinity $60 \mathrm{ppt}$, the $G$. birdiae again increased in biomass on day six (Figure 1), and remained constant until day twenty-one, after which it once again decreased until the experiment was completed, achieving final average biomass of 28.8 gMS.m $^{-2}$ (Figure 2). The biomasses of the macroalgae cultivated at salinities 0 and $10 \mathrm{ppt}$ showed a reduction from day six until the experiment ended. In the treatment with salinity $0 \mathrm{ppt}$, the $G$. birdiae entered senescence totally on day twentyseven, while on day thirty, this species submitted to salinity $10 \mathrm{ppt}$ showed a significantly decreased average biomass compared to the other treatments $\left(1.1{\mathrm{gMS} . \mathrm{m}^{-2}}^{2}\right.$ (Figure 2). The negative influence on the G. birdiae growth, when subjected to the extremes of salinity, was probably caused by a disturbance in the cellular mechanism, which inhibited the reaction centers of photosystems I and II. KIRST (1990) reported that higher or lower salinity levels induced this response, causing either the decrease or interruption of photosynthesis and the subsequent reduced growth. The growth of the G. corticata species also showed significant negative responses when exposed to extreme salinity ranges (15 and 55) (KUMAR et al., 2010).

Although the species exhibited significant differences when exposed to the salinity extremes, it also showed wide tolerance of this parameter in the intermediate salinities. The macroalgae revealed a biomass increase when subjected to salinities of $20,30,40$ and $50 \mathrm{ppt}$, during which they remained significantly unchanged throughout the experiment and achieved a final average dry biomass of $40.37,39.20,35.07$ and 36.31 gMS. $\mathrm{m}^{-2}$, respectively (Figures 1 and 2). This lack of significant differences in the G. birdiae growth in this interval indicates its ability to tolerate a wide variation in salinity, probably connected to its eurialin characteristic. In a study performed by exposing the red macroalgae Grateloupia doryphora to different salinities, it was reported that they too exhibited higher tolerance to salinities of 22 to $42 \mathrm{ppt}$ (SIMON et al., 1999), a range very similar to that observed in the present study for G. birdiae. The wide interval of salinity tolerated by the species in the present study may be linked to its ability to adapt as it inhabits the regions between the tides, which are subject to constant salinity changes.

\section{CONCLUSION}

We concluded that the salinity controls the G.birdiae growth, with the interval between 20 and $50 \mathrm{ppt}$ being the most favorable for this seaweed species to flourish. Conversely, the G. birdiae growth is adversely affected by salinities of 0 and 10ppt. Results from this study supply data that may be relevant to the cultivation of this macroalgae in a monoculture or a multitrophic system. 


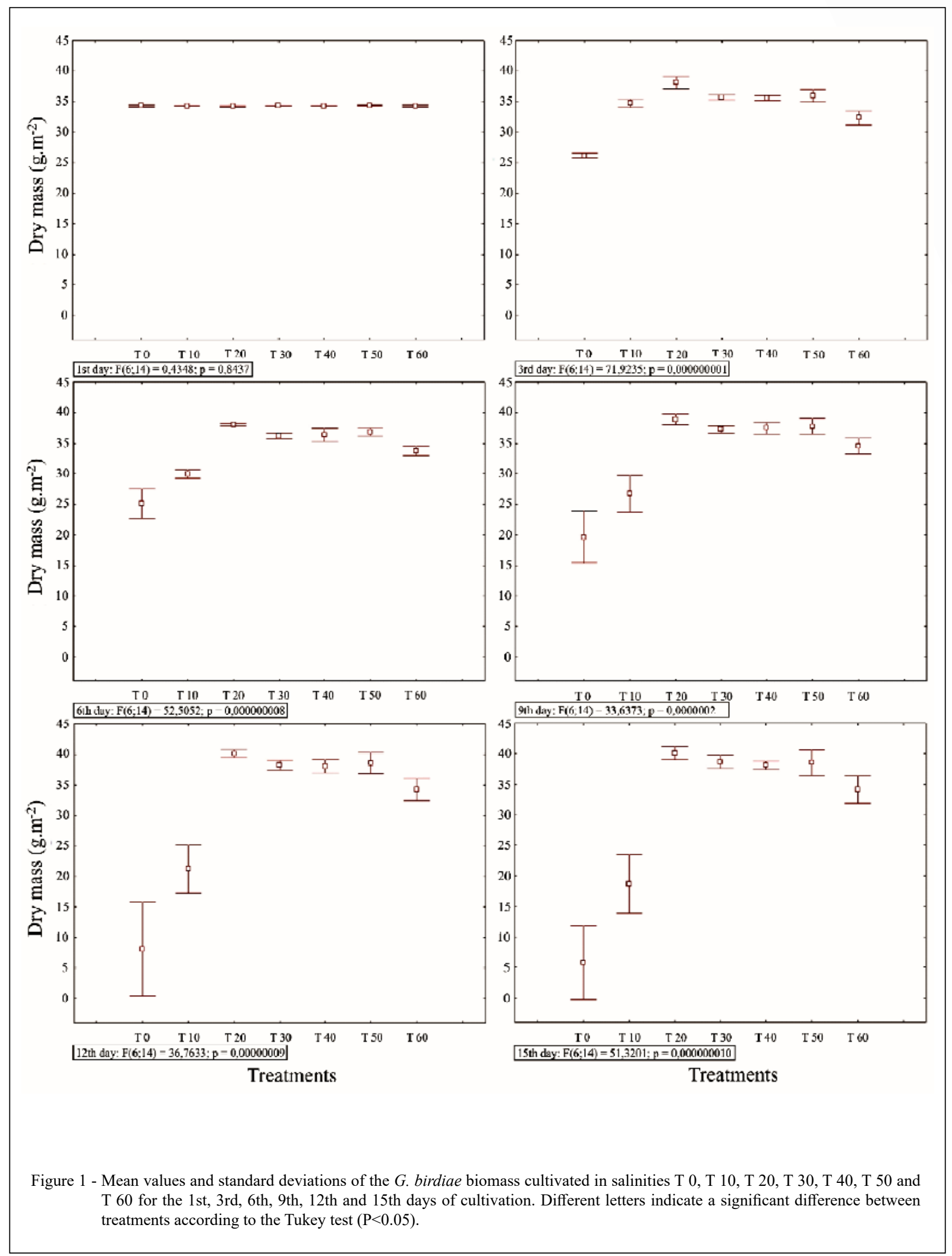

Ciência Rural, v.51, n.1, 2021. 


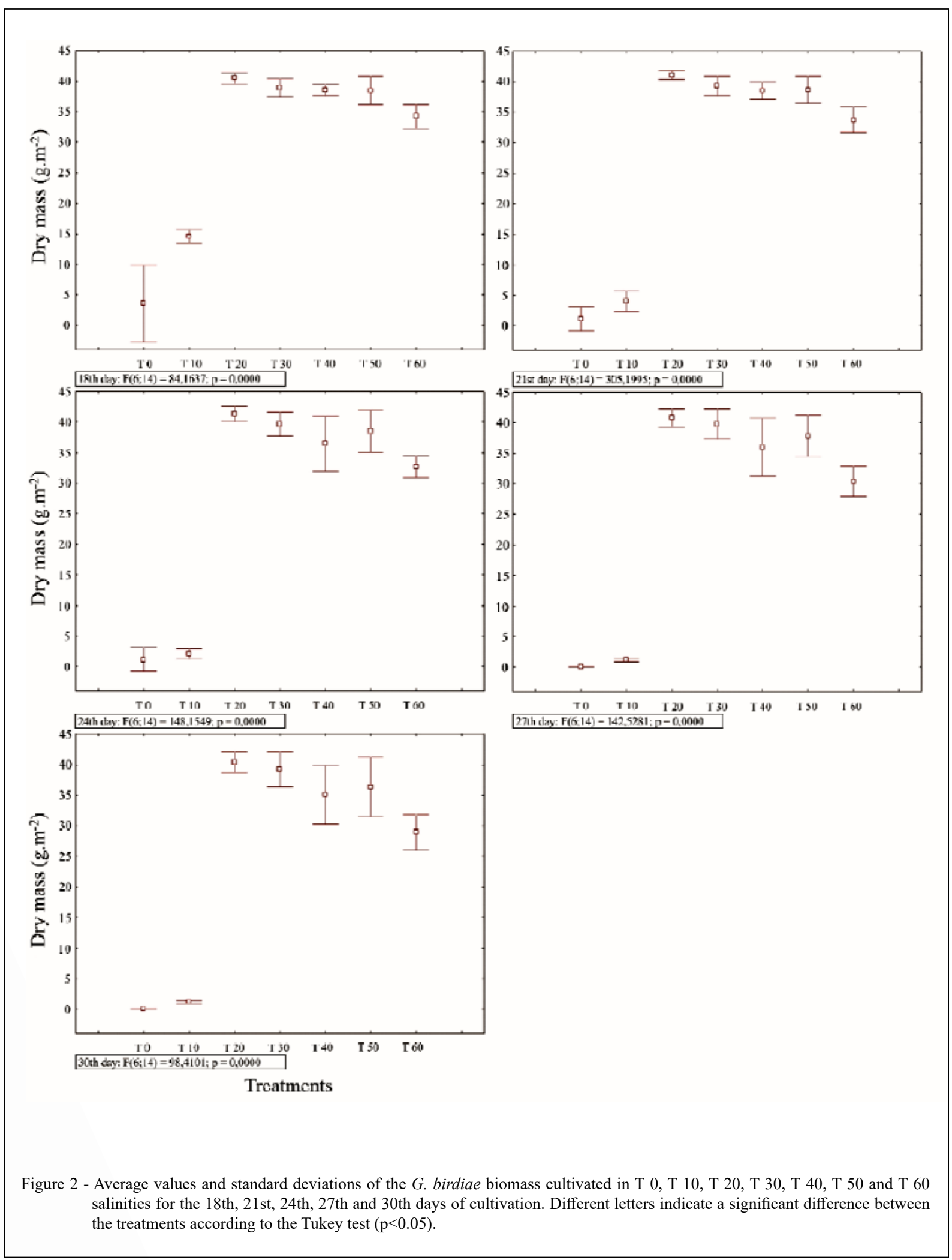

Ciência Rural, v.51, n.1, 2021. 


\section{ACKNOWLEDGMENTS}

The authors express their gratitude to the Conselho Nacional de Desenvolvimento Científico e Tecnológico (CNPq) for the financial support provided, and this study was financed in part by the Coordenação de Aperfeiçoamento de Pessoal de Nível Superior - Brasil (CAPES) - Finance Code 001. We also thank Natália Rocha Celedonio, in the Aquiculture Sector at UFERSA, and Luís Carlos Fernandes.

\section{DECLARATION OF CONFLICT OF} INTERESTS

The authors declare no conflict of interest. The founding sponsors had no role in the design of the study; in the collection, analyses, or interpretation of data; in the writing of the manuscript, and in the decision to publish the results.

\section{AUTHORS' CONTRIBUTIONS}

All authors contributed equally to the manuscript, critically reviewed and approved the final version.

\section{REFERENCES}

BATTACHARYYA, D. et al. Seaweed extracts as biostimulants in horticulture. Scientia Horticulturae, Canada, v.196, p.39-48, set. 2015. Available from: $<$ http://www.sciencedirect.com/science/ article/pii/S030442381530176X>. Accessed: Sep. 19, 2019. doi: 10.1016/j.scienta.2015.09.012.

CHOI, T. S. et al. Effect of salinity on growth and nutrient uptake of Ulva pertusa (Chlorophyta) from an eelgrass bed. Algae. Gwangju, v.25, n.1, p.17-26, nov. 2010. Available from: $<$ https://pdfs.semanticscholar.org/be37/ ca43bd78b81b008c833b6d6087c0917e80cb.pdf>. Accessed: Sep. 23, 2019. doi: 10.4490/algae.2010.25.1.017.

EDWARDS, P. Illustrated guide of seaweeds and sea grasses in vicinity of Porto Arkansas. In: Dr. Tracy and A. Villareal (Eds.). Contributions in Marine Science. Texas : Marine Science Institute, 1970. v.15, p.1-228.

FAO (Food and Agriculture Organization of the United Nations). The global status of seaweed production, trade and utilization. Globefish Research Programme, Rome, v.124, p.120, 2018. Available from: <http://www.fao.org/3/CA1121EN/ca1121en. pdf $>$. Accessed: Sep. 12, 2019.

FATH, B. D. Encyclopedia of Ecology. [Amsterdã?]: Elsevier, 2018. 2. ed. 2780 p.

KALIAPERUMAL, N. et al. Grow of Gracilaria edulis in relation to environmental factors in field cultivation. Seaweed Research and Utilisation, v.16, n.1-2, p.167-176, 1993. Available from: $<$ http://eprints.cmfri.org.in/5966/1/Article 05.pdf>. Accessed: Sep. 02, 2019.

KALIAPERUMAL, N. et al. Studies on salinity tolerance and acclimatization of some commercially important seaweeds. Seaweed Research and Utilisation, v.23, n.1\&2, p.47-53, 2001 Available from: <http://eprints.cmfri.org.in/5939/1/Article 01 . pdf $>$. Accessed: Oct. 11, 2019.
KIRST, G. O. Salinity tolerance of eukaryotic marine algae. Annual Review of Plant Physiology and Plant Molecular Biology, v.41, n.1, p.21-53, 1990. Available from: <https://www.annualreviews. org/doi/10.1146/annurev.pp.41.060190.000321>. Accessed: Sep. 1, 2019. doi: 10.1146/annurev.pp.41.060190.000321.

KUMAR, M. et al. Biochemical responses of red alga Gracilaria corticata (Gracilariales, Rhodophyta) to salinity induced oxidative stress. Journal of Experimental Marine Biology and Ecology, Bhavnagar, v.391, p.27-34, 2010. Available from: <https:// www.infona.pl/resource/bwmeta1.element.elsevier-77ea8f98f19f-3526-8305-a7ed64664922>. Accessed: Sep. 1, 2019. doi: 10.1016/j.jembe.2010.06.001.

LERAT, Y; CORNISH, M; CRITCHLEY, A. Applications of algal biomass in global food and feed markets: From traditional usage to the potential for functional products. In: BARRE, S. L.; BATES S. S. Blue Biotechnology. Wiley-VCH Verlag GmbH, 2018. Cap.5, p.143-189

MARINHO-SORIANO, E. et al. Nutrients' removal from aquaculture wastewater using the macroalgae Gracilaria birdiae. Biomass and Bioenergy, Natal. v.33, n.2, p.327-331, set. 2008. Available from: <https://www.sciencedirect.com/science/article/ pii/S0961953408001700?via\%3Dihub>. Accessed: Oct. 02, 2019. doi: 10.1016/j.biombioe.2008.07.002.

PEREIRA, D. T. et al. Effects of salinity on the physiology of the red macroalga, Acanthophora spicifera (Rhodophyta, Ceramiales). Acta Botanica Brasilica, Florianopolis, v.31, n.4, p.555-565, out./dez. 2017. Available from: $<$ http://www.scielo.br/scielo.php?script=sci_arttext\&pid $=\mathrm{S} 0102-33062017000400555>$. Accessed: Oct. 15, 2019. doi: 10.1590/0102-33062017abb0059

PEREIRA, R. \& YARISH, C. Mass production of marine macroalgae. In: JORGENSEN, S. E. \& FATH, B. D. Encyclopedia of Ecology. Vol. 3. Ecological Engineering. Oxford : Elsevier, 2008, p.2236-2247.

SCHMIDT, E. C. et al. Influence of cadmium and salinity in the red alga Pterocladiella capillacea: cell morphology, photosynthetic performance and antioxidant systems. Brazilian Journal of Botany. São Paulo, v.38, n.4, p.737-749, 2015. Available from: <https://link.springer.com/article/10.1007/ s40415-015-0183-5>. Accessed: Sep. 20, 2019. doi: 10.1007/ s40415-015-0183-5.

SIMON, C. et al. Effects of Short-Term Variations of Salinity and Temperature on the Photosynthetic Response of the Red Alga Grateloupia doryphore from Brittany (France). Botanica Marina. Berlin, v.42, n.5, p.437-440, 1999. Available from: <https:// www.degruyter.com/view/j/botm.1999.42.issue-5/bot.1999.050/ bot.1999.050.xml>. Accessed: Sep. 17, 2019. doi: 10.1515/ BOT.1999.050.

STENGEL, D. B.; CONNAN, S. Marine Algae: a source of biomass for biotechnological applications. In: STENGEL, D. B.; CONNAN, S. Natural products from marine algae methods in molecular biology: Methods and Protocols, Methods in Molecular Biology. Vol.1308. New York : Humana Press, 2015. Cap.1, p.1-37.

TORRES, P. et al. A comprehensive review of traditional uses, bioactivity potential, and chemical diversity of the genus Gracilaria (Gracilariales, Rhodophyta). Algal Research. São Paulo, v.37, p.288-306, 2019. Available from: <https://www.sciencedirect. 
com/science/article/pii/S2211926418305381?via\%3Dihub>. Accessed: Oct. 21, 2019. doi: 10.1016/j.algal.2018.12.009.

WHARTON, D. A. Life at the limits: organisms in extreme environments. Cambridge : Cambridge University Press, 2002. 320p.
YOKOYA, N. S. Controle do desenvolvimento e da morfogênese por auxinas e citocininas em três espécies de rodofíceas: Gracilariopsis tenuifrons, Grateloupia dichotoma e Solieria filiformis. 1996. 202f. Tese de Doutorado, Universidade de São Paulo.

Ciência Rural, v.51, n.1, 2021. 